\title{
EMPLOYEE ATTRACTION AND RETENTION IN THE AUSTRALIAN \\ RESOURCES SECTOR
}

\author{
Professor Kate Hutchings* \\ Department of Employment Relations and Human Resources \\ Griffith University \\ Gold Coast campus \\ Gold Coast QLD 4222 \\ AUSTRALIA \\ E-mail: k.hutchings@ griffith.edu.au \\ Professor Helen De Cieri \\ Department of Management \\ Monash University \\ P.O. Box 197 \\ Caulfield East Vic 3145 \\ AUSTRALIA \\ Email: helen.decieri@buseco.monash.edu.au \\ Dr Tracey Shea \\ Department of Management \\ Monash University \\ P.O. Box 197 \\ Caulfield East Vic 3145 \\ AUSTRALIA \\ Email: tracey.shea@buseco.monash.edu.au
}

*N. B. This research was undertaken whilst the first author was also employed at Monash University

Acknowledgment: This research is funded by an Australian Research Council Linkage grant in partnership with Chalco (China Aluminum Corporation).

Running title: Australian Resources Sector Employment Practices 


\begin{abstract}
This paper presents findings from a survey conducted in the Australian resources sector in 2009 exploring human resource (HR) managers' perceptions of how their organisational practices and external contextual changes in industrial relations legislation present challenges for the sector and influence attraction and retention of highly skilled employees. The research makes an important contribution to the literature on good employment/high involvement work practices by investigating organisational practices within the politico-legislative context of this economically significant sector. Our findings indicate that organisations have implemented a range of 'good' employment practices, while dealing with concerns about skills shortages, employee turnover, an aging workforce, and changes in legislation. We identify a need for employers to give greater attention to diversity and work-life balance issues. Further, there is a need for strategies to increase the attractiveness of work in remote locations.
\end{abstract}

\title{
KEYWORDS
}

attraction; good employment practices; resources sector; retention 


\section{INTRODUCTION}

This paper analyses senior human resource (HR) managers' perceptions of factors affecting attraction and retention of employees in the Australian resources sector. The Australian resource sector is facing skills shortages due in part to the long work hours in the industry and remote locations. The sector is also challenged by uncertainty brought by changes in federal government since late 2007, including enactment of Fair Work employment relations legislation. This paper presents findings from a survey conducted in early 2009 which provides an important analysis of the perceptions that employers have of the workplace challenges they face, and the difficulties in, and strategies for, attracting and retaining employees.

Researchers have suggested that organisations' employment practices and organisational performance is heavily influenced by the broader political, legal, technological, institutional, economic, and socio-cultural context (Paauwe, 2004; Brewster, 2007). Our research investigates how employers in this sector, which is critical to the Australian economy, perceive the impacts of legislative contextual changes. Additionally, we examine how organisations can address the lack of attractiveness of this sector through the implementation of good employment practices/high involvement work practices (see Guest, 2002; Boxall \& Macky, 2009).

There is limited extant research on employment relations or human resource management $(\mathrm{HRM})$ in the resources sector internationally. Prior research in the Australian resources sector has examined the link between strategic management and firm performance (Zheng, Rolfe, Di Milia \& Bretherton, 2007); enterprise bargaining and flexibility (Waring \& Barry, 2001); human resource management (Simons, Shadur \& Kienzle, 1999; Buchanan \& Hall, 2002) and health, safety and worker participation 
(Gunningham, 2008). Our research builds on this literature by highlighting the need to understand contextual influences on business activities with its consequent implications for attractiveness to employees and is significant in being the first research to directly investigate how employers perceive their organisational practices in relation to their ability to attract and retain employees in the Australian resources sector.

The paper begins by reviewing the resources sector context, focusing on the significance of this sector to the Australian economy and highlighting the challenges presented by current legislative influences. This is followed by a review of the literature on attraction and retention, good employment practices and high involvement work practices. Our research method is then presented, followed by discussion of the findings. The paper concludes with a summary of practical implications, research limitations and issues for future research.

\section{THE CONTEXT OF THE RESOURCES SECTOR}

Historically, the Australian economy has been very dependent upon the resources sector, which has had a sharp increase in profitability throughout the early 2000s, benefiting from high commodity prices, and foreign investment as well as high demand from China (Crawford, 2008). In 2007-8, the minerals industry comprised $8 \%$ of Australia's gross domestic product and generated $42 \%$ of Australia's exports in 2007 2008 and accounted for $37.9 \%$ of new capital investment by Australian businesses (CSIRO, 2009). Internationally, the resources sector has boomed in recent years with considerable growth from developing world economies, particularly China, which has invested heavily in resources in the developed world. The Global Financial Crisis 
(GFC) resulted in a slowing within this sector (Crawford, 2008), concerns about its continued productivity (Frith, 2008) and flow-on effects from unemployment, inflation, and interest rates (O'Brien, Valdkhani \& Townsend, 2008), yet the sector remains economically significant.

Set against this backdrop in Australia, substantive, ongoing changes to industrial relations legislation with regard to direct dealings between employers and employees at the workplace level have intensified the need for successful management of the employer-employee relationship (see Bailey, Townsend \& Luck, 2009). The Fair Work Act, enacted in 2009 by the Labor government, signalled a return to several key aspects of industrial relations of previous Labor governments including removal of the former Liberal Work Choices legislation's exemption from unfair dismissal for enterprises with 100 or fewer employees, and increased workplace entry rights for union representatives (see Fair Work Act, 2009).

Legislative change has been particularly contentious in the resources sector. Employers reacted negatively to the new unfair dismissal laws believing it to constrain their flexibility (Cooper, 2009). The employer association representing the resources sector, Australian Mines and Metals Association (AMMA), suggested the new legislation is a victory for union dominance (Cooper, 2008) and argued the case for selfregulation in employee relations (AMMA, 2007a). Conversely, some organisations favoured the move back to a centralised system with Knox (2009) claiming that decentralised bargaining is too difficult, expensive and uncertain for some firms. Unions and employees have generally reacted positively to the changes. The Construction, Forestry, Mining and Energy Union (CFMEU) has argued that, while the Fair Work Act has not done enough to reduce negative elements of Work Choices such as restrictions 
on bargaining content and unions' right of entry, the union supports the ban on any new Australian Workplace Agreements (AWAs), restoration of industry awards and 'good faith' bargaining (Sutton, 2010). Debate over legislative change mirrors developments in other countries, such as responses to re-regulation of the labour market in the United States sought by the Employee Free Choice Bill, as well as greater labour protections in emerging economies such as China.

Most recently, the Labor government's early 2010 proposal to include a resources sector supertax highlighted the strong and divergent views in employer and employee camps. The mining giants claimed it would threaten their projects, while the Australian Workers Union ran a media campaign against what they viewed as profiteering miners (Kelly, 2010). The newly appointed Prime Minister Gillard announced in late June 2010 an intention to reduce the proposed rate of the tax.

Set against this context, although Australian has an overall surplus of labour, the competition to attract and retain highly skilled labour into the resources sector will become more intense. The Chamber of Minerals and Energy of Western Australia (2009) has suggested that resource companies are already working hard to prevent loss of skilled workforces and are prioritising redeployment of employees internally. Similarly, the Federal Department of Education, Employment and Workplace Relations (2008) has emphasised the need for greater training in the resources sector. The sector faces the twin challenges of securing sufficient skilled workers to meet demand and upskilling workers to keep pace with changes in technology and work practices. 


\section{ATTRACTION, RETENTION AND GOOD EMPLOYMENT PRACTICES}

\section{Attraction and Retention}

Scholars have long noted that the ability to attract and retain high quality workers is critical to organisational competitiveness (Ulrich, 1993; Delery \& Shaw, 2001) and a stream of research in strategic HRM has examined the linkage between HR practices and firm performance and effectiveness (Boselie, Dietz \& Boon, 2005). However, critical analyses have suggested that a systematic approach to creating a workplace with high performance work systems which serve as an inimitable resource supporting the effective implementation of corporate strategy and the attainment of operational goals' (Becker \& Huselid, 1998: 53) may not be sufficient to attract and retain high skilled employees nor lead to firm performance (Combs, Liu, Hall \& Ketchen, 2006). Organisations also need to provide employee-focused good employment/ high involvement practices that build a positive workplace experience to attract and retain employees (Boxall \& Macky, 2009).

\section{Good Employment Practices}

.Much of the emphasis of 'good' employment practices has been placed on strategies to retain staff, link satisfaction and commitment to retention, and has emphasised flexible employment, communication, and family friendly work policies, telecommuting, wellbeing programmes, employment conditions and social and community practice (Zatzick \& Iverson, 2006; Beauregard \& Henry, 2009). Gill (2006) suggests that whether an organisation is a good employer can be viewed from many perspectives, including from employee, employer, industry and public perspectives. The employer's perspective (i.e. strategies safeguarding effective operations for a business), and the 
employee's perspective, (i.e. strategies securing employees commitment to the business), can substantially influence the success of the business (O'Halloran, 2005) but it should be said that employees may perceive distinct differences between organisational policy and practice. Erickson and Gratton (2007) caution that in the "war for talent', organisations will not become good employers simply by 'utilising other companies' best practices; rather, employers need to provide a 'signature experience' to cultivate a committed organisational workforce.

\section{High Involvement Work Systems}

Extending good employment practices, Boxall and Macky (2009) note that the notion of high performance work systems (HPWS) has been the focus of considerable interest over the last fifteen years but suggest that high involvement work systems (HIWS) evolve beyond HPWS' 'best practices'. Boxall and Macky (2009) propose that together work practices that relate to how work is organised, and employment practices that relate to recruitment, deployment, motivation, consultation, negotiation, development, retention, and termination, affect performance on multiple levels. Guest (2002) proffers the need for an employee-centred approach that emphasises the relationship between employees' reports about certain employment practices and their work and life satisfaction, and in so doing focuses on the employees' involvement in the relationship between employment practices and performance, yet there is no specific research reporting differences between employer and employee perceptions.

Vandenberg, Richardson and Eastman (1999) importantly note that although relying on subjective beliefs about events, HIWP are viewed as having a more powerful influence over individuals' and organisations' effectiveness than objective assessments 
of the same events (Vandenberg et al., 1999). Business practices such as work design, incentives, flexibility, training, and direction setting are seen as antecedents of HIWP which then lead to organisational commitment, job satisfaction and turnover intentions, which positively influence employees' perceptions of the attractiveness of an organisation and their consequent likelihood to remain committed to such, but more research needs to actually measure whether this occurs across sectors, industries and employers.

Drawing upon this literature to explore contextual and organisational issues associated with attraction and retention in the Australian resources sector we examine the following research questions:

- RQ1: What are the major workplace challenges facing organisations in the Australian resources sector?

- RQ2: What strategies are organisations in the Australian resources sector implementing to attract and retain employees?

- RQ3: What are the most important changes identified by employers as necessary to attract and retain employees in the Australian resources sector?

- RQ4: When seeking to attract and retain employees, what are the major difficulties being faced by organisations in the Australian resources sector?

\section{METHOD}

\section{Sample and Procedure}

The survey was mailed to senior HR managers of all 397 Australian organisations identified in Jobson's (2008) online database of companies listed on the Australian and New Zealand Stock Exchange as being involved in the Australian resources sector 
which includes organisations directly involved in mining (e.g. mines, refineries, and smelting services), oil and gas exploration (e.g. pipelines, oil and gas extraction), and ancillary services (e.g. catering, helicopter services, ports).

All potential respondents were assured of the confidentiality of data, their own anonymity, and the voluntary nature of participation. Fifty-six organisations responded to the survey resulting in a $14 \%$ response rate (or 1 in 7 organisations in the sector). Respondents were generally human resource managers $(n=33)$ or other senior management $(n=13)$ and were mostly male $(n=36)$. While this is a relatively small response rate, we note the observation of leading HR researchers, Becker and Huselid (1998): "it is becoming increasingly difficult to get organizations to participate in this form of research. The firms in our samples consistently tell us that not only are they receiving an increasing number of surveys ... but that staff cutbacks and increasing workloads have made it more difficult to find time to complete them. Our expectation is that this trend will continue for the foreseeable future". As our research was conducted during the early stages of the GFC it might be expected that the attention of executives was focused on financial matters and responding to surveys may not have been one of their priorities. Nonetheless, efforts were made to improve the response rate by sending reminders and offering a summary report of the survey findings.

Tables 1 and 2 detail the key organisational and employee characteristics of the respondent organisations. Ninety per cent of respondents were involved in mining or oil and gas exploration and most represented Australian-headquartered organisations, and as such, we do acknowledge that our findings may not be generalisable across the resources sector. The majority of respondents reported that union presence was either non-existent or between one and ten percent in their organisation. Of the respondent 
organisations, 30 are large, 21 are medium, 1 is small, and 2 are micro ( 2 did not provide firm size). The role of the senior HR and other managers in firms of this size will be quite strategic as functional areas will be largely outsourced. It would be expected that the senior HR managers would work alongside senior management in managing organisational change and as such they were targeted as being best qualified to provide detail on strategic direction in attraction and retention.

<Insert Table 1 about here>

<Insert Table 2 about here>

We acknowledge that a limitation of this study is that it focused on ascertaining the views of HR managers and that triangulating the findings with responses from other managers within the organisations as well as employees would be desirable. We have, however, provided a broader perspective of the findings by including reference to AMMA, Australian Institute of Mining and Metallurgy (AusIMM) and CFMEU documents, which indicate the degree of accordance of employer associations and unions' views with those of HR managers.

\section{Questions}

The findings presented in this paper are drawn from a survey that investigated management practices in the Australian resources sector. To assess workplace challenges, respondents were provided with a list of ten possible workplace challenges and were asked to give a yes or no response for two time periods, now and in three to five years. The challenges were: skills shortages, employee reluctance to reside remotely, an ageing workforce, employee turnover, downsizing of your workforce, planning for closure, economic downturn, workplace relations, changes in workplace 
legislation and union presence. An opportunity to add additional challenges not covered in the list was provided but this option was not utilised by any respondents..

Respondents were also asked three open-ended questions regarding how their organisation dealt with attraction and retention of employees: 1) what are the most important practices that your organisation is currently providing to attract and retain employees? 2) what are the most important changes needed for your organisation to attract and retain employees? and 3) what are the most important difficulties faced by your organisation with regard to attracting and retaining employees? . The qualitative data reported herein provides representative responses. Responses are categorised as: organisational context, good employment practices, and community and social concerns.

\section{RESULTS}

The results address each of the four research questions: workplace challenges in the resources sector; strategies employers currently use to attract and retain employees; the changes needed to attract and retain employees; and difficulties faced when attracting and retaining employees.

\section{Workplace Challenges}

Table 3 shows the responses to a series of questions addressing current and future workplace challenges. Current workplace challenges of most concern to the majority of organisations are: changes in workplace legislation (76\%), economic downturn (69\%) and skills shortages (57\%). That respondents signal difficulties in attracting employees with requisite skills does suggest a need for organisations to give greater attention to 
strategies to retain skilled employees. While skills shortages $(77 \%)$ and changes in workplace legislation (72\%) are seen to remain as dominant workplace challenges in this sector over the next three to five years, the economic downturn (48\%) is not perceived to be an issue beyond the short-term. However, challenges that are seen to be of increasing concern are: an aging workforce (58\%), workplace relations (57\%), union presence (57\%) and employee turnover (51\%).

<Insert Table 3 about here>

\section{Strategies used to attract and retain employees}

Table 4 shows the main strategies organisations in this sector are currently using to attract and retain employees. Respondents emphasised provision of competitive remuneration (including overtime pay, bonuses, annual anniversary allowances, options, profit sharing, share purchase plans, subsidised rent, cash in leave, extra superannuation for two or more years service, living away from home allowances, contract completion bonus, salary sacrifice, car leasing). They also referred to the need to provide good work conditions (including free parking, free gym, employee assistance programs in health and financial planning, family-friendly work culture, respect for diversity, travel opportunities, high safety, fly in-fly out (FIFO) schemes offering less time away from home, nine day fortnight). Several respondents also emphasised training and development opportunities to increase employees' ability to attain secure and permanent employment.

In respect to organisational context some respondents emphasised the use of employee recognition systems or a family friendly culture for attracting and retaining employees. Other respondents believe company reputation and company culture are 
important to the attraction and retention of employees with one respondent mentioning enlightened management and a frontline management program. Additional issues highlighted included: proximity to a capital city, and working in a small company with good interaction and an ethical approach to employees.

<Insert Table 4 about here>

\section{Important changes needed to attract and retain employees}

Table 5 shows the most important changes perceived by employers as being needed to attract and retain employees. Several respondents referred to the constraints brought by economic downturn but overall focus was placed on issues expected to be of ongoing importance. The main strategy for attraction and retention is improved opportunities for training and development, particularly tertiary training and other government training schemes. Improving recruitment practices, maintaining and increasing competitive salaries and providing opportunities for career development such as opportunities for management positions at the local level were also seen as important potential changes. Additional emphasis was also placed on improving the organisational culture and greater employee involvement with their work.

Specific organisational strategies noted were: improved manager-to-employee communications, the provision of a better and stronger management team and the development of leadership skills (including targeted supervisor development). Respondents also suggested that they should have their own employment relations strategy which should emphasise work-life balance and an understanding of Generation Y. Despite the popularity of sustainability in the parlance of many Australian 
organisations, only one respondent identified social responsibility as being relevant in attracting and retaining employees.

$<$ Insert Table 5 about here>

\section{Difficulties faced by organisations in attracting and retaining employees}

Table 6 shows the most common difficulties faced when attempting to attract and retain employees. The two major difficulties reported by participating organisations are skills shortages and competition for high quality staff. Despite high salaries in the sector, particularly in mines in remote areas, the continuing lack of qualified and experienced applicants, particularly in specialised areas such as engineering or skilled trades, is a common challenge. Additionally, competition for staff is a major concern for smaller organisations that do not have the financial resources to offer the same salaries, flexible working conditions, and other support, provided by multinational corporations.

Many respondents emphasised the challenge in attracting staff to remote locations as small towns offer few services or social activities and, though wages are high, costs of living are seen as prohibitive. One respondent expanded on this point in mentioning the negative image of the resources sector amongst community and environmental groups and suggested that this has a flow-on effect in attracting staff generally. The aging workforce, lack of local senior management opportunities and limited career paths are also noted as difficulties faced by some organisations.

$<$ Insert Table 6 about here> 


\section{Concerns of the Employer Association, HR Managers and the Union}

It is important to note the degree of consistency between the major industry group, the key union for the sector, and responses from HR managers in respect to challenges facing the sector in attraction and retention. Table 7 summarises the key issues in regards to consistency of concerns.

<Insert Table 7 about here>

\section{DISCUSSION}

\section{Unionisation}

Almost two thirds of respondents said that they have between no more than ten percent of employees as members of a union with a fifth suggesting union presence is a workplace challenge and almost three quarters suggesting that changes in workplace legislation are a current challenge in the sector. AMMA has previously objected to the possibility that legislative changes would give unions automatic access to conduct membership recruitment campaigns in union-free workplaces (AMMA, 2007a). For their part, unions have critiqued mining companies for use of AWAs and the Fair Work Act for restricting union right of entry (Sutton, 2010).

\section{Good employment practices}

Our findings suggest the some respondent organisations have implemented a range of good employment practices including competitive remuneration and bonuses, training and development, and improved workplace benefits, with a small number providing flexible, non-standard work. This indicates some companies have high involvement work systems and suggests companies support the view that provision of a positive 
organisational environment can lead to attraction and retention of employees (Zatzick \& Iverson, 2006; Boxall \& Macky, 2009). However, the findings provide little indication of employee or union engagement in developing employee relations strategies.

It is not clear whether the surveyed organisations are cognisant of the need to better accommodate work-life balance as only two mentioned family-friendly workplaces. The most highlighted factor as being critical in attracting and retaining staff was remuneration and bonuses. While employers noted skill shortages, an aging (and retiring) workforce, and employee turnover as being pertinent issues into the immediate and longer-term future, current emphasis was placed on corporate image, a communicative culture and quality leadership. This indicates that some organisations are making moves towards high involvement work systems (Boxall \& Macky, 2009) but not Erickson and Gratton's (2007) 'signature experience'. Respondents suggested the need to ensure employees feel challenged in their work but did not specifically state AMMA's advocacy for management strategies to achieve greater employee involvement in decision making. (AMMA, 2007b).

\section{Implications of remote locations and non-standard work for work-life balance}

While a small percentage of organisations emphasised having a family-friendly culture and good working conditions, the industry overall faces challenges given that many of the work locations are remote and support facilities minimal, making employment generally unattractive. Many of the jobs in mining and energy are located remotely and have FIFO positions occupied by men, who may have spouses/dependants living in cities that provide educational and medical facilities, a better standard of housing, and a 
broader range of sporting and community activities than they available in remote locations.

In addition to FIFO work, the resources sector has a large percentage of employees engaged in non-standard work, such as temporary, contract work, and seasonal employment, as well as many who do shift work in intensive and extended schedules. Such work assists organisational competitiveness in meeting demands for production and export, but also has important implications for employees' personal and/or family relationships, and health and safety issues, including stress (Collison, 1998; Zheng et al., 2007). Amongst other recommendations, AusIMM (2009) suggest that in remote areas government provide child care centres with operating hours to accommodate employees (many of whom undertake shift work) and that such care could be tax-deductible or fringe-benefits tax-free if provided by employers. Additionally the CFMEU reports that work-intensive rosters of 14 days of 12 hour shifts followed by 7 days off - a very common roster in mining companies - means that childrearing responsibilities fall unequally on non-working spouses (Colley, 2005).

\section{Women in the resources sector}

Although growth in the resources sector over the last decade has greatly increased the number of employees overall, women remain under-represented.. Sixty two percent of respondents reported that $14 \%$ or less of their workforce is comprised of women, with expected higher percentages in large multinational corporations (with well developed HRM departments and policies) and ancillary services firms (such as catering). AusIMM and the Women in Mining Network Committee (WIMNet) found that women account for only $18 \%$ of the mining workforce while they constitute $42 \%$ of the 
Australian workforce overall (AusIMM, 2009). The low participation rates of women are, in part, likely due to the unattractiveness of work locations as well as lack of recruitment and training policies for increasing women's participation and managerial opportunities..

In a report on gender equity in the mining industry, AusIMM (2009) explored key issues affecting equitable participation in mining and identified a number of on-going barriers and assumptions/bias affecting individuals' complete participation in, and access to pay equity, support services, training and promotion opportunities. They argued the need for organisations to provide much greater flexibility and support for diversity, better communication channels and educational resources to address inequities (AusIMM, 2009). The CFMEU has also highlighted the need for more parttime work, job sharing, and longer maternity and parental leave (Colley, 2005). Our research suggests that employers need to achieve more involvement of employees through training and communication, and to make the industry more attractive through greater recognition of work-life issues (Bardoel, De Cieri \& Santos, 2008).

\section{Specific practices for individual employees}

None of the respondents mentioned whether there are particular aspects of remuneration or work that are especially appealing to individual sectors of their workforce. It may be the case that, while efforts are being made to identify 'best practice' to attract and retain employees, consideration has not been given to the need to provide a flexible range of practices which will be perceived as offering value across the workforce. Given a general belief amongst employer groups that work legislation will give organisations less flexibility, there is increased need for firms to think creatively about how they 
attract high quality employees; one way in which this may be done is to identify aspects of 'good' employment appealing to different groups of employees (Bhattacharya, Gibson \& Doty, 2005).

\section{IMPLICATIONS AND ISSUES FOR FUTURE RESEARCH}

\section{Implications for Practice}

Scales (2006) suggests that part of the problem with skills shortages currently being experienced in the resources sector lies with employers who pay high wages when commodity prices are high and then cut employee numbers 'to the bone' when prices drop, forcing highly skilled workers to move to other industry sectors. Internationally, companies compete to employ skilled labour through migration and temporary work visas. Our findings suggest that in response to skills shortages and critical changes in legislation, resource sector organisations utilise at least some 'good' employment practices, such as safe working conditions, high remuneration relative to other sectors and urban locations, and effective communication strategies. However, more needs to be done by employers in this sector to attract employees through offering more flexible work practices for employees and better work-life balance, particularly for firms operating in remote locations. Environmental conditions, including infrastructure, such as schools and medical facilities are also considerations for employers seeking to attract a workforce to remote locations. It is evident that there is disparity between employers' views of issues around attraction and retention and employee perspectives on these issues. 


\section{Limitations and Issues for Future Research}

The research is limited by having a relatively small response rate of $14 \%$ although as Harzing (1997) has noted, mail surveys in the industrialised world typically have response rates between $6 \%$ and $16 \%$.

A second limitation is that the majority of the responses are from large-medium firms, which have large HR departments and HR managers with a strategic role and could be expected to have more progressive HR practices around attraction and retention. Hence, the sample may not be representative of all organisations in the sector.

A third limitation is that we only studied employers' perceptions of the challenges facing the resources sector. The HR managers are well placed to indicate the factors they believe affect attraction and retention in their organisations and we have broadened the representativeness of views by referring to AMMA and CFMEU documents to show accordance with the employer association and major union for the sector. Nonetheless, future research needs to analyse employee views of the factors which attracted them to, and contributed to them remaining with, organisations in the sector. Future research might also explore whether different categories of employees (e.g. knowledge workers, professionals, labourers) were attracted and retained by differing practices/benefits. Additionally, future research could directly seek the views of union representatives for their insights into challenges in attraction and retention and their own involvement in employment relations decision making in the sector.

\section{CONCLUSION}

This research is significant in providing the views of HR managers in the resources sector; this sector is globally important yet relatively under-researched with regard to 
management practices. Recognising the size and strength of the resources sector coupled with the demands faced with regard to attraction and retention of employees, it could be concluded that employers in this sector are developing a distinctive good employment approach which recognises some of the limitations presented by their operations in remote locations. It is also evident that there is room for further progress if high involvement work systems are also to be operationalised. Our findings should assist managers to identify and benchmark their progress in the context of changing external conditions. 


\section{REFERENCES}

Australian Institute of Mining and Metallurgy (AusIMM) (2009) Gender Pay Equity and Associated Issues for Women in Mining - Survey Report. Carlton South, Australia: AusIMM.

Australian Mines and Metals Association (AMMA) (2007a) An Analysis of Coalition and ALP Workplace Relations Policies. Melbourne Australia: AMMA.

Australian Mines and Metals Association (AMMA) (2007b) Employee Engagement - a Lifetime of Opportunity: An Analysis of the Employee Engagement Experiences of AMMA Members Using the Four Quadrant Model of Employee Relations and Organisational Effectiveness. Melbourne Australia: AMMA.

Australian Mines and Metals Association (AMMA) (2010) AMMA Workplace Relations Policy. http://www.amma.org.au/representation/policy/WR.html. Accessed 3rd July 2010.

Bailey J, Townsend K, Luck E (2009) WorkChoices, ImageChoices and the marketing of new industrial relations. Work, Employment and Society 23, 285-304.

Bardoel EA, De Cieri H, Santos C, (2008) A review of work-life research in Australia and New Zealand. Asia Pacific Journal of Human Resources 46, 316-333.

Beauregard TA, Henry LC (2009) Making the link between work-life balance practices and organizational performance. Human Resource Management Review 19(1), 922.

Becker BE, Huselid MA (1998) High performance work systems and firm performance: A synthesis of research and managerial implications. Research in Personnel and Human Resources Journal 16(1), 53-101. 
Bhattacharya M, Gibson DE, Doty DH (2005) The effects of flexibility in employee skills, employee behaviours, and human resource practices on firm performance. Journal of Management 31(4), 622-640.

Boselie P, Dietz G, Boon C (2005) Commonalities and contradictions in HRM and performance research. Human Resource Management Journal 15 3), 67-94.

Boxall P, Macky K (2009) Research and theory on high-performance work systems: progressing the high involvement system. Human Resource Management Journal 19(1), 3-23.

Brewster C (2007) Comparative HRM: European views and perspectives. International Journal of Human Resource Management 18(5), 769-787.

Buchanan J, Hall R (2002) Teams and control on the job. Journal of Industrial Relations 44(3), 397-417.

Chamber of Minerals and Energy Western Australia (2009) Resource Sector Optimistic in face of Economic Challenges, $23^{\text {rd }}$ January 2009 media release. http://www.cmewa.com.au/UserFiles/File/Media\%20Releases\%202009/090123MPR-Media. Accessed 13th July 2009.

Colley P (2005) A career and a life in mining: What needs to be done?. Paper presented to the Sustainable Development 2005 Conference of the Minerals Council of Australia. November 2005, Alice Springs: MCA.

Collison DL (1998). Shift-ing lives: Work-home pressure in the North Sea oil industry. The Canadian Review of Sociology and Anthropology 35(3), 301-324.

Combs J, Liu Y, Hall A, Ketchen D (2006) How much do high- performance work practices matter? A meta-analysis of their effects on organizational performance. Personnel Psychology 59, 501-528. 
Cooper R (2008) Advance Australia fairly now that Work Choices is dead and buried' Sydney Morning Herald, $27^{\text {th }}$ November: 13.

Cooper R (2009) Forward with fairness: Industrial relations under Labor in 2008. Journal of Industrial Relations 51(3), 285-296.

Crawford A (2008) Qld Resource Sector Cuts 'Will Hurt National Economy'. http://www.abc.net.au/news/stories/2008/12/17/2448710.htm; Accessed $9^{\text {th }}$ April 2009.

CSIRO (2009) Minerals Down Under: Helping to Transform the Minerals Industry in Australia. $\quad$ http://www.csiro.au/org/Minerals-Down-Under-Overview.html. Accessed $9^{\text {th }}$ April 2009.

Delery J, Shaw J, (2001) The Strategic Management of People in Work Organizations: Review, Synthesis and Extension. Research in Personnel and Human Resource Management 20, 165-197.

Department of Education, Employment and Workplace Relations (2008) 'Training Essential to meet Resource Sector Demand. 20 ${ }^{\text {th }}$ August 2008 media release, http://www.deewr.gov.au/Ministers/OConnor/Media/Releases/Pages/Article_0810 27 101236.aspx, Accessed 13 $3^{\text {th }}$ July 2009.

Erickson TJ, Gratton L (2007) What it means to work here. Harvard Business Review 85(3), 104-112.

Fair Work Act of 2009. No. 282009.

http://www.workplace.gov.au/NR/rdonlyres/94109AFC-BF1D-4B70-9262-

B00BCBA673C0/0/fwact2009.pdf. Accessed 30th April 2009.

Frith D (2008) Muddy waters hide reality. Business Review Weekly 30, 25, 95.

Gill R (2006) Reputation and Employer of Choice for Australian Business. Melbourne: 
Aviva Australia.

Guest D (2002) Human resource management, corporate performance and employee wellbeing: Building the worker into HRM. Journal of Industrial Relations. 44(3), $335-358$.

Gunningham N (2008) Occupational health and safety, worker participation and the mining industry in a changing world of work. Economic \& Industrial Democracy 29(3), 336-361.

Harzing A-W (1997) Response rates in international mail surveys: Results of a 22 country study. International Business Review 6(6), 641-665.

Jobson (2009) Online Database of Listed Companies in the Australian and New Zealand Stock Exchange. Sydney: Dunn and Bradstreet. www. http://jobsons.dnb.com.au/Login.aspx; Accessed on 5 ${ }^{\text {th }}$ April 2009.

Kelly P (2010) Trust lost in pivotal supertax stand-off. The Australian, $22^{\text {nd }}$ May: 11.

Knox A (2007) Better the devil you know? An analysis of employers' bargaining preferences in the Australian hotel industry. Journal of Industrial Relations 51(1), 25- 44.

O'Brien M, Valadkhani A, Townsend K (2008) The Australian Labour Market in 2007. Journal of Industrial Relations 50(3), 383-398.

O'Halloran L (2005) A worldwide effort to summon corporations to the table'. Australian Financial Review 21 ${ }^{\text {st }}$ April 2005: 20.

Paauwe J (2004) HRM and Performance: Unique Approaches for Achieving Long Term Viability. Oxford: Oxford University Press.

Scales M (2006). Two Steps Forward, One Back. Canadian Mining Journal 127(6), 5.

Simons R, Shadur M, Kienzle R. (1999) Explanations for the relationship between 
human resource practices and organisational strategy in the Australian mining industry. International Journal of Employment Studies 7(1), 17-32.

Sutton J (2009) The New Fair Work Act. Statement issued $3^{\text {rd }}$ July 2009. Construction, Forestry, Mining and Energy Union.

http://www. Cfmeu.net.au/infopages/3268html. Accessed on $21^{\text {st }}$ May 2010.

Ulrich D (1993) Profiling organizational competitiveness: Cultivating capabilities. Human Resource Planning, 16(3), 1-17.

Vandenberg RJ, Richardson HA, Eastman LJ (1999) The impact of high involvement work processes on organizational effectiveness. Group and Organization Management 24(3), 300-339.

Waring P, Barry M (2001) The changing frontier of control in coal: Evidence from a decade of enterprise bargaining in the Australian black coal mining industry. Australian Bulletin of Labour 27(3), 216-238.

Zatzick CD, Iverson RD (2006) High-involvement management and workforce reduction: Competitive advantage or disadvantage? Academy of Management Journal 49(5), 999-1015.

Zheng C, Rolfe J, Di Milia L, Bretherton P (2007) Strategic people management of coal mining firms in Central Queensland. Management Research News 30(9), 689-704. 
Table 1

Characteristics of respondent organisations

\begin{tabular}{|c|c|c|c|}
\hline & & $\mathrm{N}$ & $\%$ \\
\hline \multirow[t]{4}{*}{ Main activity } & Mining \& energy & 32 & 57 \\
\hline & Oil \& gas exploration & 15 & 27 \\
\hline & Ancillary services (e.g. catering) & 8 & 14 \\
\hline & No response & 1 & 2 \\
\hline \multirow[t]{2}{*}{ Location of corporate HQ } & Australia & 39 & 70 \\
\hline & Elsewhere & 17 & 30 \\
\hline \multirow[t]{4}{*}{ Number of worksites } & One worksite & 13 & 23 \\
\hline & Two worksites & 15 & 27 \\
\hline & More than two worksites & 26 & 46 \\
\hline & No response & 2 & 4 \\
\hline \multirow[t]{7}{*}{ Employees in union } & None & 20 & 36 \\
\hline & 1 to $10 \%$ & 14 & 25 \\
\hline & 11 to $25 \%$ & 3 & 5 \\
\hline & 26 to $50 \%$ & 5 & 9 \\
\hline & 51 to $75 \%$ & 3 & 5 \\
\hline & 76 to $100 \%$ & 4 & 7 \\
\hline & No response & 7 & 11 \\
\hline
\end{tabular}


Table 2

Employment status of employees in respondent organisations

\begin{tabular}{|c|c|c|}
\hline Employee status & Mean & Std Dev \\
\hline Full-time & 87.6 & 17.2 \\
\hline Part-time & 3.0 & 4.0 \\
\hline Casual & 7.8 & 16.1 \\
\hline Seasonal & 0.3 & 1.4 \\
\hline
\end{tabular}


Table 3

Workplace challenges in the Australian resources sector

Workplace challenge

Skills shortages

Changes in workplace legislation

An ageing workforce

Workplace relations

Union presence

Employee turnover

Economic downturn

Employee reluctance to reside remotely

Downsizing of your workforce

Planning for closure
Now \%

57

76

39

46

20

38

69

31

42

7
3-5 years \% 77

72

58

57

57

51

48

44

27

18 


\section{Table 4}

Strategies used to attract and retain employees in the Australian resources sector

\begin{tabular}{|c|c|c|c|}
\hline Type of strategy & Strategy & $\mathrm{N}$ & $\%$ \\
\hline \multirow[t]{5}{*}{ Organisational context } & Company reputation and culture & 4 & 9 \\
\hline & Excellent working environment & 5 & 11 \\
\hline & High quality leadership, quality people & 4 & 9 \\
\hline & Good communications & 1 & 2 \\
\hline & High ethics and professional standards & 1 & 2 \\
\hline \multirow[t]{8}{*}{ Employment Practices } & $\begin{array}{l}\text { Competitive remuneration (e.g. above } \\
\text { market average) }\end{array}$ & 25 & 55 \\
\hline & Bonuses (e.g. contract completion & 8 & 18 \\
\hline & bonus) & & \\
\hline & Training and development opportunities & 10 & 22 \\
\hline & $\begin{array}{l}\text { Benefits packages/workplace benefits } \\
\text { (e.g. gym facilities) }\end{array}$ & 8 & 18 \\
\hline & $\begin{array}{l}\text { Interesting/challenging work, } \\
\text { international career opportunities }\end{array}$ & 4 & 9 \\
\hline & Rostering (e.g. flexible rosters) & 6 & 13 \\
\hline & Secure contracts, permanent work & 5 & 11 \\
\hline $\begin{array}{l}\text { Community and social } \\
\text { concerns }\end{array}$ & None stated & & \\
\hline
\end{tabular}

Note: Only 45 respondents (80\%) answered this question; percentages are based on this figure. 
Table 5

Most important changes needed to attract and retain employees in the Australian resources sector

\begin{tabular}{|c|c|c|c|}
\hline Type of strategy & Strategy & $\mathrm{N}$ & $\%$ \\
\hline \multirow[t]{4}{*}{ Organisational context } & $\begin{array}{l}\text { Better communication (e.g. executive } \\
\text { management team) }\end{array}$ & 5 & 12 \\
\hline & $\begin{array}{l}\text { Better management teams (e.g. training, } \\
\text { communication) }\end{array}$ & 3 & 7 \\
\hline & Develop leadership skills & 2 & 5 \\
\hline & $\begin{array}{l}\text { Better site culture (e.g. equality, } \\
\text { company values) }\end{array}$ & 4 & 9 \\
\hline \multirow[t]{7}{*}{ Employment Practices } & Training and development & 12 & 28 \\
\hline & $\begin{array}{l}\text { Competitive salary and remuneration } \\
\text { structure }\end{array}$ & 6 & 14 \\
\hline & $\begin{array}{l}\text { Clear career paths (e.g. create local } \\
\text { management positions) }\end{array}$ & 2 & 5 \\
\hline & Better employee engagement & 2 & 5 \\
\hline & $\begin{array}{l}\text { Secure work-life balance opportunities } \\
\text { (e.g. telecommuting) }\end{array}$ & 4 & 9 \\
\hline & $\begin{array}{l}\text { Better understanding of the Generation } \\
\text { Y workforce }\end{array}$ & 2 & 5 \\
\hline & $\begin{array}{l}\text { Fair, equitable and lawful working } \\
\text { conditions }\end{array}$ & 1 & 2 \\
\hline $\begin{array}{l}\text { Community and social } \\
\text { concerns }\end{array}$ & Better town services & 1 & 2 \\
\hline
\end{tabular}

Note: Only 43 respondents (77\%) answered this question; percentages are based on this figure. 
Table 6

Difficulties faced when attracting and retaining employees in the Australian resources sector

\begin{tabular}{|c|c|c|c|}
\hline Type of strategy & Strategy & $\mathrm{N}$ & $\%$ \\
\hline \multirow[t]{2}{*}{ Organisational context } & Standard of supervision & 1 & 2 \\
\hline & HR practices not valued & 1 & 2 \\
\hline \multirow[t]{4}{*}{ Employees } & $\begin{array}{l}\text { Skills shortages (e.g. engineering, } \\
\text { skilled trades) }\end{array}$ & 11 & 25 \\
\hline & $\begin{array}{l}\text { Competition for staff (e.g. } \\
\text { remuneration) }\end{array}$ & 11 & 25 \\
\hline & Lack of career path & 2 & 5 \\
\hline & Aging workforce & 1 & 2 \\
\hline \multirow{4}{*}{$\begin{array}{l}\text { Community and social } \\
\text { concerns }\end{array}$} & Uncertain financial climate & 6 & 14 \\
\hline & Remote locations & 6 & 14 \\
\hline & Lack of government support & 1 & 2 \\
\hline & $\begin{array}{l}\text { Industry image (e.g. community } \\
\text { environmental concerns) }\end{array}$ & 1 & 2 \\
\hline
\end{tabular}

Note: Only 44 respondents (79\%) answered this question; percentages are based on this figure. 
Table 7

Comparison of Employer Association (AMMA), HR Managers, and Union (CFMEU) Views

\begin{tabular}{|c|c|c|c|c|}
\hline Issue & Employer Association view & HR Managers' view & Union view & Consistency \\
\hline $\begin{array}{l}\text { Changes in } \\
\text { Workplace } \\
\text { Legislation - Fair } \\
\text { Work Act }\end{array}$ & $\begin{array}{l}\text { Legislation a victory for union } \\
\text { dominance }\end{array}$ & $\begin{array}{l}\text { Major issue now and into the } \\
\text { future }\end{array}$ & $\begin{array}{l}\text { Value restoration of industry } \\
\text { awards and good faith bargaining, } \\
\text { concerns about restrictions on } \\
\text { bargaining content and unions } \\
\text { right of entry }\end{array}$ & $\begin{array}{l}\text { Strong consistency between } \\
\text { AMMA and HR Managers - } \\
\text { CFMEU very divergent view }\end{array}$ \\
\hline Union presence & $\begin{array}{l}\text { Favours right of entry but says } \\
\text { legislative changes will give } \\
\text { unions access to union-free } \\
\text { workplaces to recruit members }\end{array}$ & $\begin{array}{l}\text { Very low level of unionisation in } \\
\text { organisations }\end{array}$ & $\begin{array}{l}\text { Concerns about restrictions on } \\
\text { unions' right of entry under Fair } \\
\text { Work Act and mining companies' } \\
\text { continuing use of existing high } \\
\text { wage AWAs }\end{array}$ & $\begin{array}{l}\text { Consistency between AMMA } \\
\text { and HR Managers - very } \\
\text { divergent view from CFMEU }\end{array}$ \\
\hline Skills shortages & Major issue for the sector & $\begin{array}{l}\text { Major issue for the sector now and } \\
\text { into the future - competition for } \\
\text { high quality staff }\end{array}$ & Major issue for the sector & $\begin{array}{l}\text { Strong consistency of views } \\
\text { between AMMA, HR } \\
\text { Managers and CFMEU }\end{array}$ \\
\hline $\begin{array}{l}\text { Good } \\
\text { conditions }\end{array}$ & $\begin{array}{l}\text { Advocate role of management in } \\
\text { working with employees in } \\
\text { identifying needs }\end{array}$ & $\begin{array}{l}\text { Organisations highlighted need to } \\
\text { expand employee assistance, } \\
\text { family friendly work culture, } \\
\text { flexible work } \\
\text { Changes needed focused primarily } \\
\text { on training and development, } \\
\text { competitive salaries, improved } \\
\text { communication and leadership }\end{array}$ & $\begin{array}{l}\text { Need for more part-time work, job } \\
\text { sharing and longer } \\
\text { maternity/parental leave }\end{array}$ & $\begin{array}{l}\text { Strong consistency between } \\
\text { AMMA and HR Managers } \\
\text { Some consistency between HR } \\
\text { Managers and CFMEU in } \\
\text { identifying areas for } \\
\text { improvement. HR Managers } \\
\text { focus on extrinsic rewards and } \\
\text { role of organisational leaders - } \\
\text { CFMEU focuses on work-life } \\
\text { balance }\end{array}$ \\
\hline
\end{tabular}




\begin{tabular}{|c|c|c|c|c|}
\hline $\begin{array}{l}\text { Organisational } \\
\text { context }\end{array}$ & $\begin{array}{l}\text { Advocate management strategies } \\
\text { to achieve greater employee } \\
\text { involvement in decision making }\end{array}$ & $\begin{array}{l}\text { Company reputation and culture } \\
\text { important }\end{array}$ & $\begin{array}{l}\text { Need for greater union presence } \\
\text { and involvement in decision } \\
\text { making }\end{array}$ & $\begin{array}{l}\text { Strong consistency between } \\
\text { AMMA and HR Managers } \\
\text { CFMEU divergent view - } \\
\text { advocates stronger role for } \\
\text { unions }\end{array}$ \\
\hline $\begin{array}{l}\text { Community and } \\
\text { social } \\
\text { issues/remote } \\
\text { location }\end{array}$ & $\begin{array}{l}\text { Low participation of women in the } \\
\text { sector outside ancillary services. } \\
\text { General unattractiveness of remote } \\
\text { locations - need for government to } \\
\text { provide more support e.g. child } \\
\text { care tax-free }\end{array}$ & $\begin{array}{l}\text { Not part of current strategy for } \\
\text { attraction/retention. but work in } \\
\text { remote locations needs to be more } \\
\text { attractive - need for better town } \\
\text { services and facilities }\end{array}$ & $\begin{array}{l}\text { Need for company and/or } \\
\text { government child care support } \\
\text { given work-intensive rosters }\end{array}$ & $\begin{array}{l}\text { Strong consistency between } \\
\text { AMMA, HR Managers and } \\
\text { CFMEU on challenges posed } \\
\text { by remote locations }\end{array}$ \\
\hline
\end{tabular}

